\title{
Comparison between Effect of Adding Asphalt Emulsion and Portland Cement on Engineering Properties of Sand River Subgrade Soil
}

\author{
Dr. Khawla H. H. Shubber
}

\begin{abstract}
This study presents an attempt of experimental study on the effect of adding asphalt emulsion and Portland cement on the engineering properties of sand poorly graded river soil used as subgrade soil in pavement construction. The soil brought from sides of Al-Kufa River in Najaf state middle west of Iraq. Asphalt emulsion used in this study is that manufactured for surfacing and cold paving proposes. While Portland cement is that used in construction building. Percent of adding are $(0,3,6,9,12$ and 15$) \%$ by weight. Properties of soil studied and presented in this paper are compaction, optimum water content, CBR, and direct shear. Results showed that the adding of asphalt emulsion and cement increase the dry density in different rate. While the optimum water content decrease with increasing asphalt emulsion and increase with increasing cement added. Direct shear of soil stabilized with cement is higher than both natural soil and that stabilized with asphalt emulsion. CBR values showed the same trend of direct shear test results.
\end{abstract}

Keywords:- soil compaction, stabilization, river soil, asphalt emulsion, Portland cement, $\mathrm{CBR}$, direct shear.

\section{Introduction}

Under the effect of heavy traffic loading, high temperatures and water damages, specific requirements are essential to control quality of highway pavement materials and subgrade soil properties. Improving the properties of soil by stabilization is considered as a means of fulfilling design criteria. The stabilization is usually affected by controlling the void ration of the soil by introducing a cementing additive or waterproofing agent, or by injecting a substance to fill the pore volume.

There are several techniques for stabilization, and the selection of an appropriate technique depends on the nature of soil and environmental sensitivity or both [Newman, et.al, 2011]. It has been reported in many studies that soil stabilization has been widely used as an alternative to substitute the lacking of suitable material on site. Stabilization of soils to improve strength and durability properties often relies on cement, lime, fly ash, and asphalt emulsion. These materials are inexpensive, relatively easy to use and apply, and provide benefits to many different soil types [Ige, \& Adeleye, 2012].

Dr. Khawla H. H. Shubber

Engineering College / University of Kufa

Iraq
The last 20 years have seen several emulsion-based new technologies for road construction and repair, as well as significant improvements over previous emulsion systems. These include ultrathin hot-mix friction courses with modified emulsion bond coat; DRM (spray-applied crack seal with emulsion seal surfacing); scrub seal with modified emulsified binder; glass fiber-reinforced chip seal; trackless tack coats; warm mix using emulsion or foamed asphalt; and improved chip seal systems. Several new systems for cold mix have also been commercialized [Delmar, 2006].

In 2013, research aims to analyze in details the soil stabilization method which utilizes Portland cement and bitumen emulsion in improving soil properties. As a result, this will increase the pavement bearing capacity. The combination of Portland cement and bitumen emulsion are beneficial for the purpose of increasing the stiffness and also the elasticity of soil stabilized layer. The importance of soil stabilization using Portland cement and bitumen in improving pavement's performances by increasing bearing capacity of its layer. [Mojtaba S. B et.al 2013].

A proposed dense-graded gravel base material was treated with an anionic slow setting emulsion with low viscosity (SS-1). Dynamic resilient modulus and permanent deformation tests were performed to assess the effect of curing and temperature on stiffness and resistance to the repeated traffic load. This study showed that high resilient modulus and low deformation values were attained for 7 days curing at $24^{\circ} \mathrm{C}$. The low temperature slows the breaking process of the emulsion and causes the emulsion aggregate mixtures to have a lower resistance to repeated loading [Ahmed Sh., 2014].

Another research review on cement kiln dust (CKD) usage in soil and waste utilization and the results of experimental investigation on its usage in building block manufacturing and soil stabilization. The experimental results clearly showed that the use of $34 \%$ CKD may bring the $\mathrm{pH}$ of sludge above 10, which is enough to stabilize the sludge. Furthermore, the final concentrations of heavy metals were found to be within acceptable international limits [Rahman et.al 2011]. Federal and state highway engineers have a renewed interest in "perpetual pavement" which will benefit from "perpetual foundations". Millions of dollars can be saved by soil subgrade stabilization in comparison to cutting out and replacing the unstable subgrade soil [Joel, 2003].

The present research aims to attempt improving sand poorly graded soil properties by treated it with asphalt emulsion and Portland cement experimentally. The studied properties are compaction, optimum water content, California Bearing ratio (CBR), and direct shear. 


\section{Materials and Methods:-}

Soil used in this research, brought from side's river of Kufa in Najaf state located in middle west of Iraq, about $160 \mathrm{~km}$ south west of Baghdad, was characterized by conventional tests and results were compared with specifications in Iraq [SCRB, 2003] for using soil as subgrade soil. The soil samples were obtained from a depth of (1.5) m below the natural ground surface. Gradation of soil particles is shown in figure (1). While, the results of physical tests of natural soil are summarized in Table (1). According to test results, the soil is sand poorly graded with high percent of dark fine particles as compared with Unified Soil Classification system (USCS) [ASTM D2487 06].

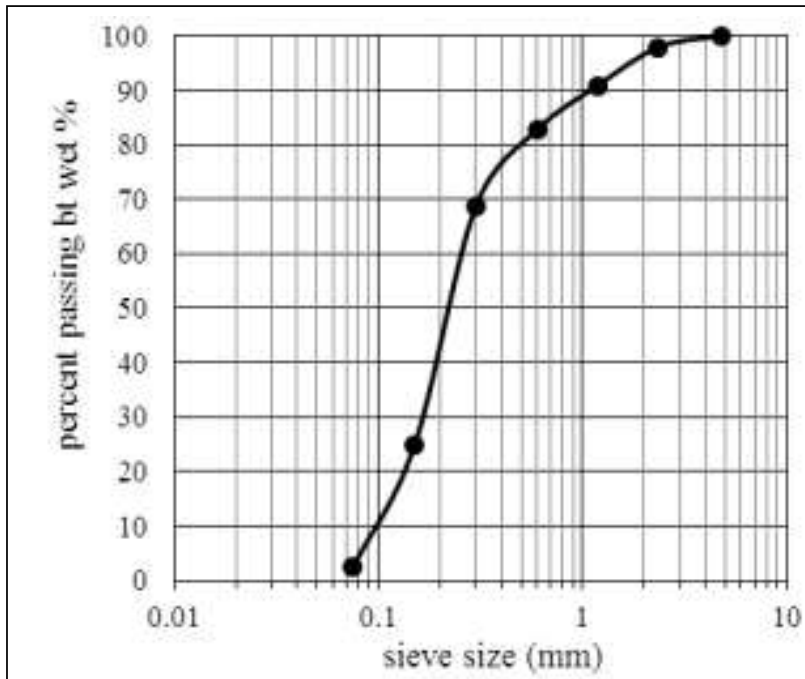

Figure (1) Grain Size distribution of Soil Used

Table (1) summary of physical properties and classification test results of soil

\begin{tabular}{|c|c|}
\hline Property & results \\
\hline Maximum Dry Unit Weight $\left(\mathrm{kN} / \mathrm{m}^{3}\right)$ & 16.5 \\
\hline Optimum Water Content (\%) & 15.51 \\
\hline Specific Gravity (Gs) & 2.7 \\
\hline Initial Water Content (\%) & 2.89 \\
\hline Liquid Limit (LL) \% & 0 \\
\hline Plastic Limit (PL) \% & 23 \\
\hline$\%$ passing sieve No.200 & 2.5 \\
\hline $\mathrm{D}_{10} \%$ & 10 \\
\hline $\mathrm{D}_{30} \%$ & 12 \\
\hline $\mathrm{D}_{60} \%$ & 26 \\
\hline $\mathrm{Cc}$ & 1.11 \\
\hline $\mathrm{Cu} \%$ & 2.6 \\
\hline CBR & 4.6 \\
\hline Soil Classification According to (USCS) & SP \\
\hline
\end{tabular}

Portland cement was used after comparing physical properties with the Specification limit (AASHTO M 85-74), as shown in Table (2); the Portland cement of Kufa factory used in all the tests of this research. Asphalt emulsion used in this study is anionic slow setting emulsion with low viscosity (SS-1) manufactured by Henkel Polybit Industries in UAE. All test results show that the chosen materials confirm specifications requirements and suitable for testing program and within scope of research.

Table (2) summary of physical and chemical properties test results of Portland cement.

\begin{tabular}{|l|c|l|}
\hline \multicolumn{1}{|c|}{ Properties } & Result & $\begin{array}{l}\text { Spec. } \\
\text { limit }\end{array}$ \\
\hline Chemical tests & 20.3 & \\
\hline $\mathrm{Sio}_{2}$ & 1.89 & $\leq 2.5 \%$ \\
\hline $\mathrm{So}_{3}$ & 0.77 & $\leq 1.5 \%$ \\
\hline Insoluble residue & 0.59 & $\leq 4 \%$ \\
\hline Loss on ignition Physical tests \\
\hline \multicolumn{2}{|c|}{} \\
\hline Initial settling time (min.) & 137 & $\geq 45$ min \\
\hline Final settling time (hours) & 240 & $\geq 10 \mathrm{~h}$ \\
\hline $\begin{array}{l}\text { Compressive strength @ } \\
\text { 3day(Mpa) }\end{array}$ & 17.1 & $\geq 15$ (Mpa) \\
\hline $\begin{array}{l}\text { Compressive strength @ } \\
7 \text { day(Mpa) }\end{array}$ & 28.0 & $\geq 23$ (Mpa) \\
\hline $\begin{array}{l}\left.\text { Fineness (cm }{ }^{2} / g m .\right) \text { by } \\
\text { Blaine method }\end{array}$ & 2769 & $\geq 2500$ \\
\hline
\end{tabular}

\section{Experimental Program:-}

Testing program presented here can be illustrated in the following paragraphs:

Soil classification tests were performed firstly including physical properties of soil with routine standard tests. Tests include grain size distribution, that determined according to (ASTM D922-72) with dry sieving. Atterberg limits, Liquid and plastic limits tests were carried out on soil passing sieve No.4. The liquid limit was determined according to (BS 1377:1972, Test No. 3). Specific gravity, determined according to (BS 1377: 1975, Test No.6 (B)). Water content, was determined in accordance with (BS 1377: 1975, Test (A), Head, 1980). And California Bearing Ratio (CBR) test, as stated in the specification (ASTM D 558).

Standard Proctor compaction tests were carried out to determine the moisture-density relationship for natural soil and soil treated with asphalt emulsion and Portland cement. The test planning to obtain as follows:

- Group one: soil tested in the natural case without any additive.

- Group two: soil tested with $(3,6,9,12,15) \%$ of asphalt emulsion.

- Group three: soil tested with $(3,6,9,12,15) \%$ of Portland cement.

Standard Proctor compaction tests were carried out for the untreated and treated soil to determine the moisture-unit weight relationship according to (ASTM D 698, 2003). A mold of (101.6) $\mathrm{mm}$ in diameter and with a height of (115.5) $\mathrm{mm}$ was used. Samples were compacted in three equal layers each hammered by (25) blows using a (2.5) $\mathrm{kg}$ hammer dropped from $(305.5) \mathrm{mm}$ height. Each test result depended was an average of three tested samples.

After completing moisture-unit weight relationships, optimum asphalt emulsion, Portland cement, that provide maximum dry density, was computed. And in order to ensure the enhancement in other engineering properties of stabilized soil, California Bearing Ratio (CBR) and direct shear was performed in two cases. One test result (an 
average of 3 samples) for soil without any additives and anther two test results with the optimum Portland cement and asphalt emulsion.

California Bearing Ratio (CBR) test is one of the most commonly used methods to evaluate the strength of a subgrade soil, subbase, and base course material for design of thickness for highways and airfield pavement. CBR test, performed according to ASTM D1883-14, is penetration test meant for the evaluation of subgrade strength of roads and pavements. The results obtained by these tests are used with the empirical curves to determine the thickness of pavement and its component layers. That is the most widely used method for the design of flexible pavement.

Direct shear test performed according to ASTM D3080. The sample is subjected to a controlled normal stress and the upper part of the sample is pulled laterally at a controlled strain rate or until the sample fails. The applied lateral load and the induced strain are recorded at given internals.

\section{Results and Dissuasions:}

experimental works implemented according to research testing program explanted above. As mentioned earlier, according to the Unified Soil Classification System (USCS), the selected soil can be classified as sand poorly graded with high percent of dark fine particles (SP).

The relationship between dry density and water content for tested soil treated with Portland cement are shown in Figure (2). For each percent added, density increase with water content increase reaching specific value, then the relationship take reverse trend and density decreasing with increasing water content, as usual. The research planning aimed to treat soil with $(3,6,9,12,15) \%$ of additives. In cement treated soil case these percent caused increasing in dry density until reaching maximum values for adding $9 \%$ then densities began to decrease. While, figures (3) shows the same relationship for soil samples treated with asphalt emulsion. Figure (3) illustrate that optimum asphalt emulsion that caused higher dry density is $12 \%$.

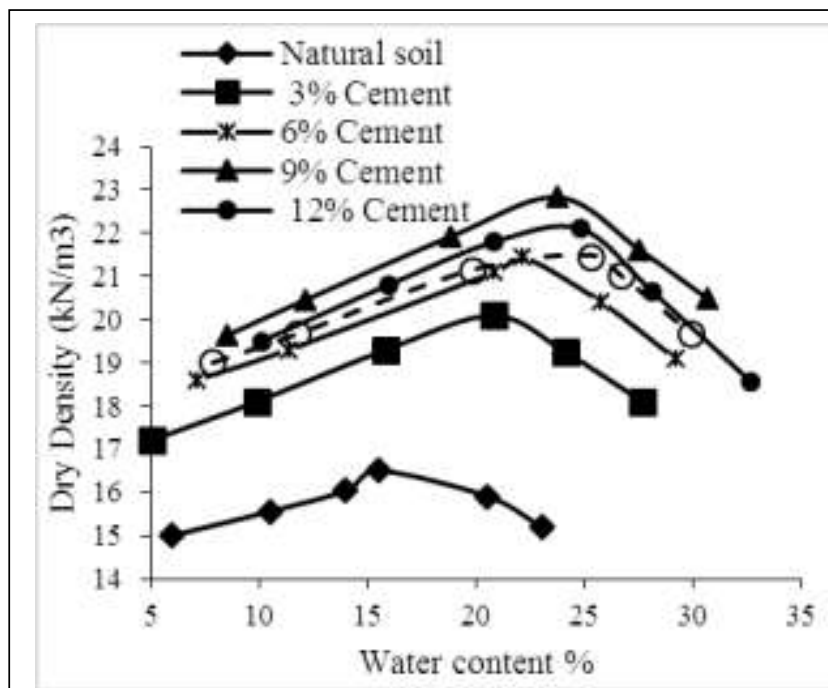

Figure (2) Standard Compaction Curves for Soil Treated with Cement

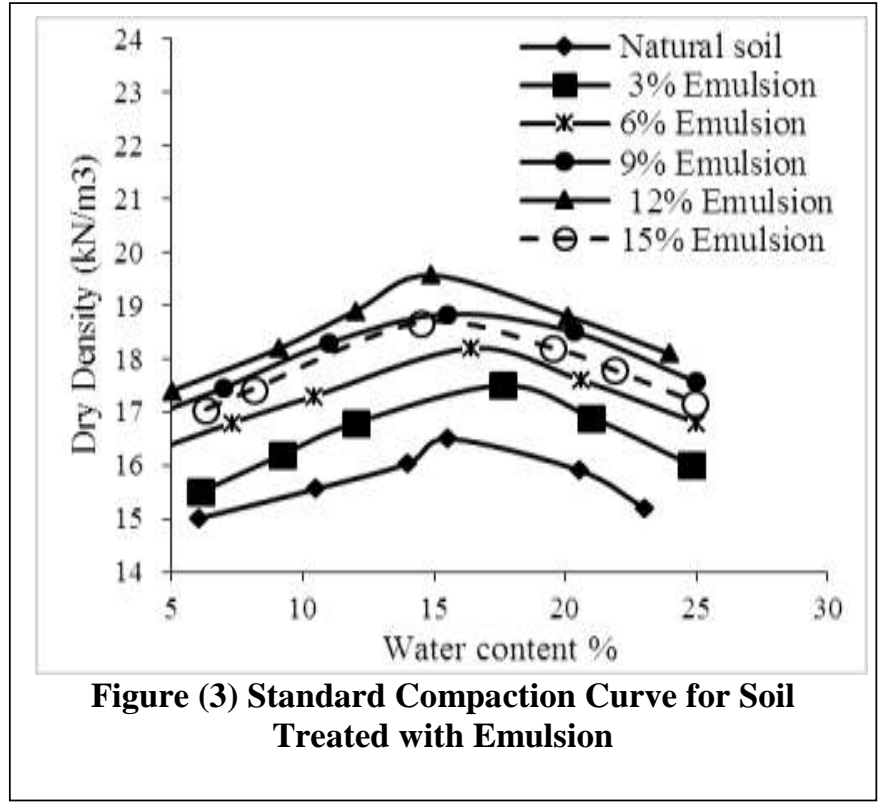

For comparison between effect of adding Portland cement and asphalt emulsion on density and optimum water content, maximum dry density and corresponding optimum water content for each percent added plotted in figure (4 \&5) respectively. Figure (4) shows that soil treated with cement had higher dry densities for all percent added. While figure (5) illustrates that adding cement increasing optimum water content continuously, while, adding asphalt emulsion decreasing it in reverse amount. This behavior retained to hydration action of cement that need extent amount of water, on the other side, water content in emulsion provide extra amount of water in the mix.

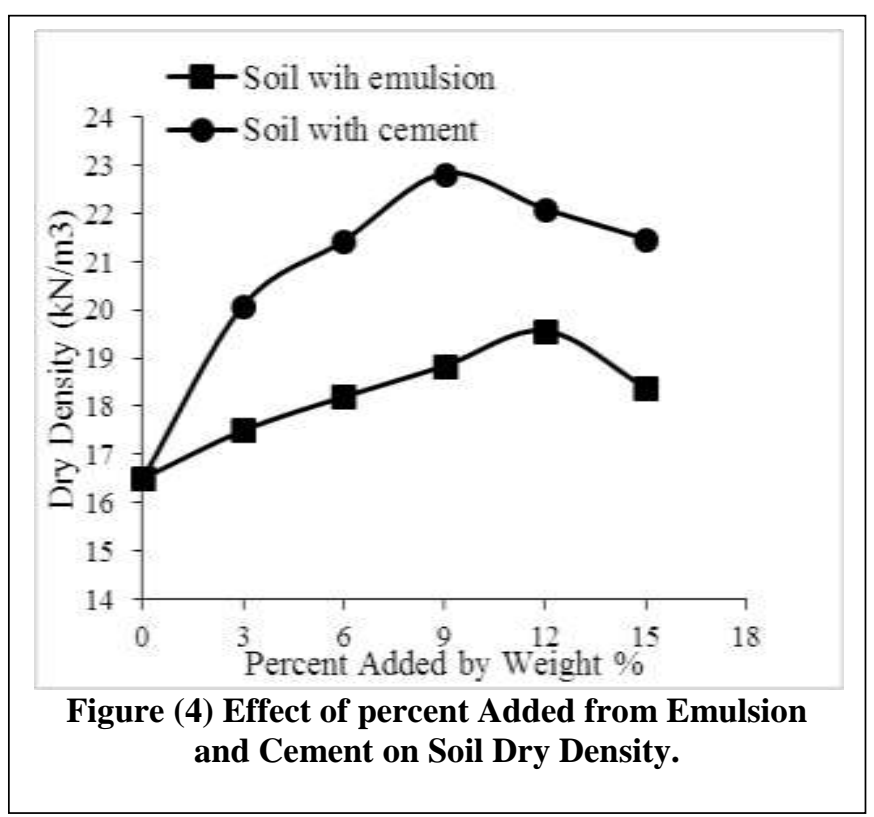


Proc. of the Fourth Intl. Conf. Advances in Civil, Structural and Mechanical Engineering- CSM 2016

Copyright (C) Institute of Research Engineers and Doctors, USA .All rights reserved.

ISBN: 978-1-63248-093-4 doi: 10.15224/ 978-1-63248-093-4-19

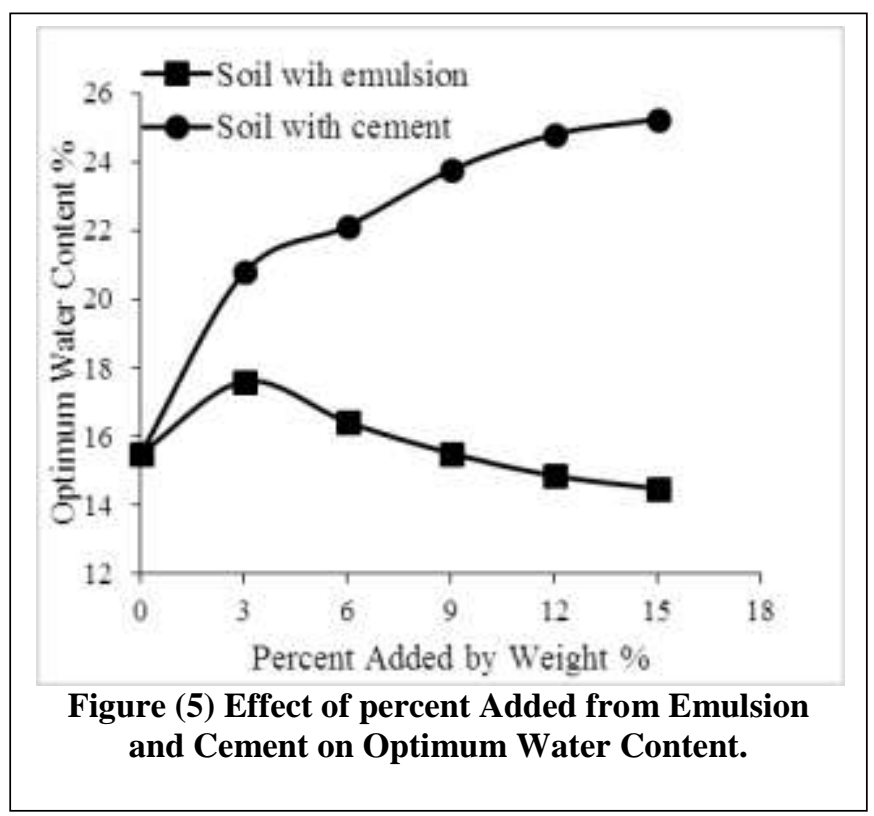

Rate of change in dry density and optimum moisture content resulting from treated with cement and emulsion shown in figure $(6 \& 7)$ respectively. As shown in figure 6 , adding $9 \%$ by weight Portland cement increasing dry density about $38 \%$ from initial density (i.e. maximum dry density of natural soil), more than that caused by adding $12 \%$ of asphalt emulsion by approximate $19 \%$. On the other hand, corresponding water content of adding $9 \%$ cement increase optimum water content about $52 \%$ form initial percent (i.e. optimum water content of natural soil). While, adding $12 \%$ of asphalt emulsion decreasing optimum water content about $20 \%$ as shown if figure (7).

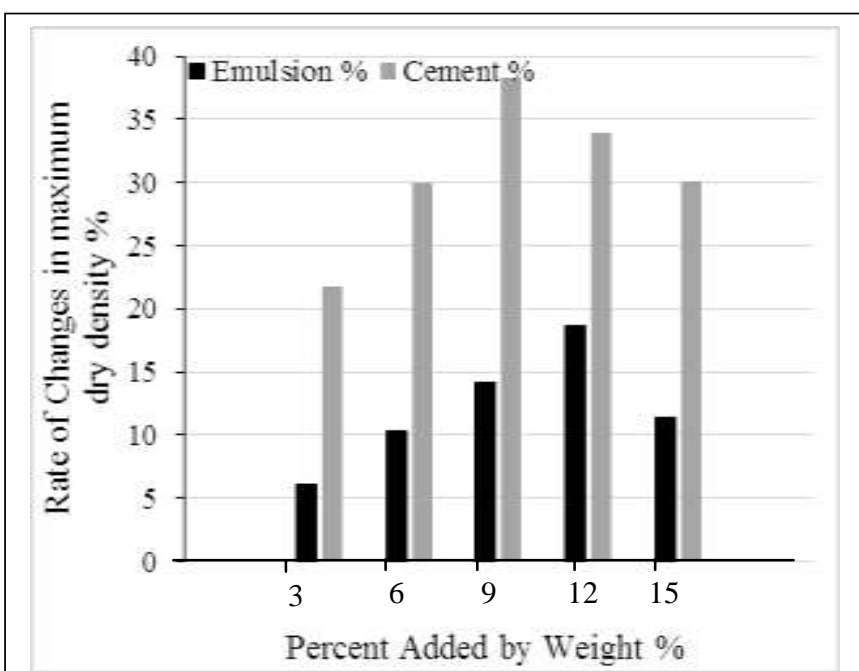

Figure (6) Dry Density Rate of Change for Percent Added from Emulsion and Cement.

Figure (8) shows effect of adding asphalt emulsion and Portland cement on CBR values. Portland cement increasing CBR values in approximately 5 times form initial values.
Taking in consideration, the tested cement treated samples was after compaction, i.e. no curing condition
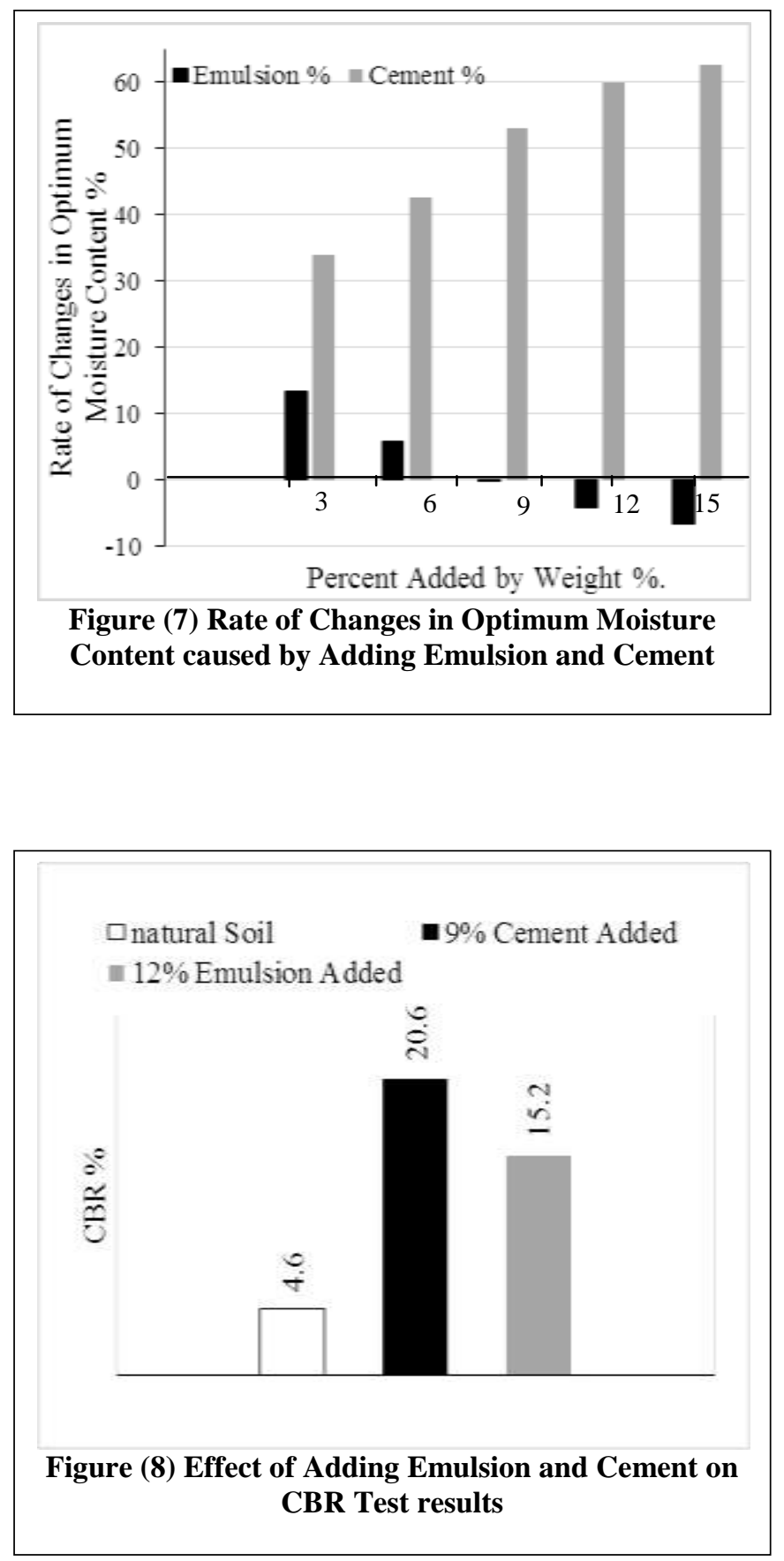

Finally, figure (9) illustrate the effect of treated soil with asphalt emulsion and Portland cement on direct shear test. Soil treated with Portland cement will be stronger than that treated with asphalt emulsion. Where, direct shear test result increasing an approximate twice than of natural soil. On the other hand, soil treated with asphalt emulsion increasing direct shear test result in about (50-85)\% from that of natural soil have. 


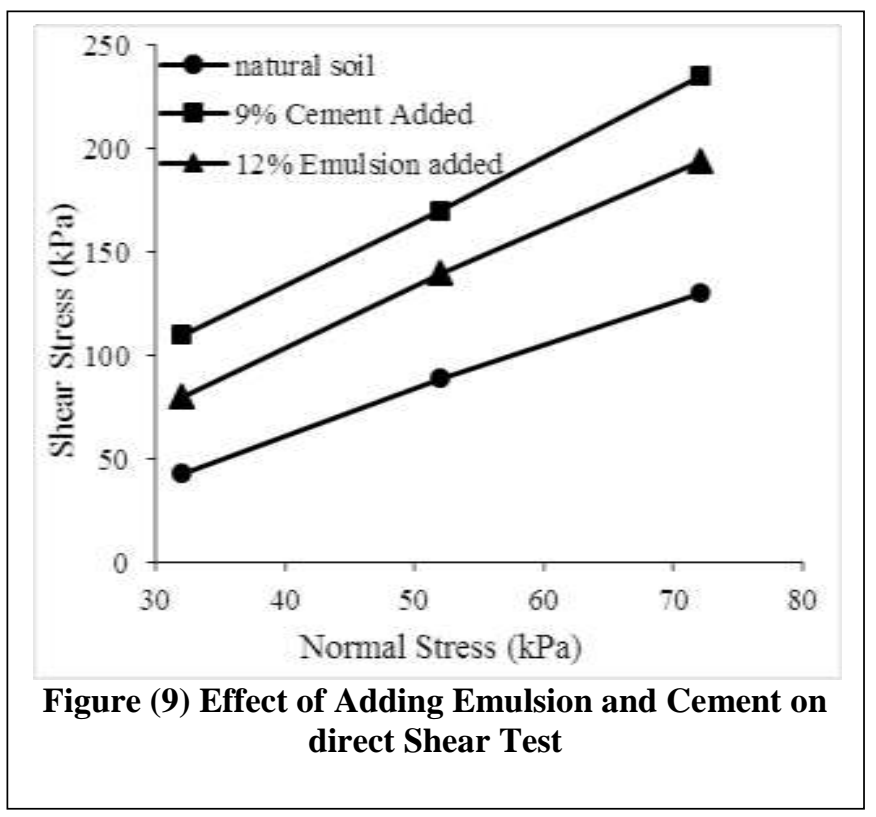

\section{Conclusions:}

The following points are drawn from experimental testing program carried out on river soil treated with asphalt emulsion and Portland cement as a stabilizer. As mentioned earlier, different percent by weight added and compaction properties, CBR values, and direct shear observed:

1- Adding both of asphalt emulsion and Portland cement improving soil engineering properties;

2- Adding both of asphalt emulsion and Portland cement increasing soil density;

3- Soil maximum dry density established at $12 \%, 9 \%$ by weight added from asphalt emulsion and Portland cement respectively;

4- Portland cement increase soil density in about $19 \%$ more than that caused by adding asphalt emulsion, with lower percent added by $3 \%$;

5- Adding asphalt emulsion reduce optimum water content while adding Portland cement increase it;

6- Because of above point, soil stabilized with asphalt emulsion can be depend in hot weather sites;

7- CBR values for soil treated with Portland cement higher than that of natural soil and soil treated with asphalt cement;

8- Portland cement added doubling the shear strength of natural soil, while asphalt emulsion improve it in about one and half times of its.

\section{References:}

AASHTO, AASHTO Guide for Design of Pavement Structures. 1993, Washington, D.C: American Association of State Highway and Transportation Officials;
Ahmed Shalaby, 2014, "Laboratory Performance of Asphalt Emulsion Treated Base for Cold Regions Applications" Conference of the Transportation Association of Canada Montreal, Quebec;

ASTM Standards, (2003), "Roads and Paving Materials" Annual Book of the American Society for Testing and Materials Standards, Section 4, Vol. 04-03;

ASTM Standers. (2003). "Soil and Rock (I)". Volume 04.08;

ASTM Designation: D 2487 - 06, 2000, "Standard Practice for Classification of Soils for Engineering Purposes (Unified Soil Classification System)" United States.

British Standard Institution BS 1377. (1975). "Method of Testing Soils for Civil Engineering Purposes". London;

Delmar R. Salomon, 2006 "Asphalt Emulsion Technology" transportation research circular e-c102, Transportation Research Board, Characteristics of Bituminous Materials Committee;

Ige, O.O. and Adeleye O.K., 2012 " Engineering Properties of Acrylic Resin on lime stabilized Soil" Transnational Journal of Science and Technology, December 2012 edition vol.2, No.11;

Joel H. Beeghly, 2003, "Recent Experiences With Lime-Fly Ash Stabilization Of Pavement Subgrade Soils,Base, and Recycled Asphalt" International Ash Utilization Symposium, Univ. of Kentucky, Center for Applied Energy Research, Lexington, KY, Oct. 20-22, 2003;

Mojtaba S. B., Amiruddin I., Behnam K., Mohamad H. H., Ramez A. A., 2013 "The Potentials of Portland Cement and Bitumen Emulsion Mixture on Soil Stabilization in Road Base Construction" Jurnal Teknologi, eISSN 2180-3722 | ISSN 0127-9696, pp.67-72;

Newman, K., Gill, C., and T. McCaffrey, 2011: "Stabilization of Silty Sand Combinations of Hydraulic Cements and Polymer Emulsion", www.strucroad.com/files/pdfs/cementcomparison 445263 839.pdf, accessed on 29/10/2011;

Rahman M. K., S. Rehman \& O. S. B. Al-Amoudi, 2011 "Literature Review On Cement Kiln Dust Usage in Soil and Waste Stabilization And Experimental Investigation" IJRRAS 7 (1) April;

State Commission of Roads and Bridges (SCRB/R5), 2003: General Specification for Roads and Bridges. Republic of Iraq, Ministry of Housing and Construction, Department of Planning and Studies, Baghdad, Revised Edition, Addendum No.3. 